Int. J. Electrochem. Sci., 15 (2020) $7001-7012$

\title{
Oxygen evolution electrocatalytic properties of perovskite-type oxides obtained by PVP sol-gel route: Part II. The effect of partial substitution of $\mathrm{Sm}$ for $\mathrm{Sr}$ in $\mathrm{La}_{0.4} \mathrm{Sr}_{0.6} \mathrm{CoO}_{3}$
}

\author{
Narendra Kumar Singh ${ }^{*}$, Priya Sharma, Manish Kumar Yadav and Reena Parihar \\ Department of Chemistry, Faculty of Science, University of Lucknow, Lucknow-226007, India \\ *E-mail: nksbhu@yahoo.com, singh_narendra@1kouniv.ac.in
}

doi: $10.20964 / 2020.07 .81$

Received: 9 March 2020 / Accepted: 2 May 2020 / Published: 10 June 2020

\begin{abstract}
This paper deals the findings of quaternary perovskite-type oxides, $\mathrm{La}_{0.4} \mathrm{Sm}_{\mathrm{x}} \mathrm{Sr}_{0.6-\mathrm{x}} \mathrm{CoO}_{3}(0 \leq \mathrm{x} \leq 0.4)$, which is the extended research work obtained by further substitution $\mathrm{Sm}(0.2$ to $0.4 \mathrm{~mol})$ for $\mathrm{Sr}$ in the ternary perovskite oxide of $\mathrm{La}_{0.4} \mathrm{Sr}_{0.6} \mathrm{CoO}_{3}$ prepared by PVP sol-gel route. The cyclic voltammogram $(\mathrm{CV})$ showed similar redox peaks; one anodic an anodic $\left(\mathrm{Ep}_{\mathrm{a}}=489 \pm 20 \mathrm{mV}\right)$ and corresponding cathodic $\left(\mathrm{Ep}_{\mathrm{c}}=355 \pm 25 \mathrm{mV}\right)$ with each oxide electrode in the potential region 0.0-0.7 V. The anodic polarization study in $1 \mathrm{M} \mathrm{KOH}$ at $25^{\circ} \mathrm{C}$ indicates that the substitution of $\mathrm{Sm}(0.2$ and $0.3 \mathrm{~mol})$ increased the electrocatalytic property of the material. However, a reduction in electrocatalytic activity is observed with $0.4 \mathrm{~mol} \mathrm{Sm}$-substitution. At potential $\mathrm{E}=800 \mathrm{mV}, \mathrm{La}_{0.4} \mathrm{Sm}_{0.2} \mathrm{Sr}_{0.4} \mathrm{CoO}_{3}\left(\mathrm{j}=191.9 \mathrm{mAcm}^{-2}\right)$ showed about 5 times higher electrocatalytic activity than base oxide; $\mathrm{La}_{0.4} \mathrm{Sr}_{0.6} \mathrm{CoO}_{3}\left(\mathrm{j}=37.6 \mathrm{mAcm}^{-2}\right)$. A reduction in Tafel slope has also been observed upto 0.3 mol Sm-substitution. Similar trend was also found in the case of thermodynamic study, such as standard entropy of activation $\left(\Delta S^{\text {*\# }}\right)$, standard enthalpy of activation $\left(\Delta \mathrm{H}^{\circ \#}\right)$ and standard electrochemical energy of activation $\left(\Delta \mathrm{H}_{\mathrm{el}}{ }^{\circ \#}\right)$ of the materials. Some physicochemical techniques like X-ray diffraction (XRD) and scanning electron microscope (SEM) have been used to analyze the synthesized products.
\end{abstract}

Keywords: Quaternary perovskite-type oxides, PVP method, XRD, Electrocatalytic activity, Thermodynamic parameters

\section{$\underline{\text { FULL TEXT }}$}

(C) 2020 The Authors. Published by ESG (www.electrochemsci.org). This article is an open access article distributed under the terms and conditions of the Creative Commons Attribution license (http://creativecommons.org/licenses/by/4.0/). 